\title{
DNA Polymerase Eta
}

National Cancer Institute

\section{Source}

National Cancer Institute. DNA Polymerase Eta. NCI Thesaurus. Code C91287.

DNA polymerase eta $(713 \mathrm{aa}, \sim 78 \mathrm{kDa}$ ) is encoded by the human POLH gene. This protein plays a role in repair of UV-induced pyrimidine dimers in DNA. 